\title{
Pattern of injuries in road traffic accidents cases reporting to accident and emergency department of a hospital in Maharashtra
}

\author{
Yasho Chaturvedi ${ }^{1}$, Rashid Nehal Khan ${ }^{2 *}$, Ravi Rautji ${ }^{3}$, K V Radhakrishna ${ }^{4}$ \\ ${ }^{1}$ PG Resident, ${ }^{2}$ Assistant Professor, ${ }^{3}$ Professor \& HOD, ${ }^{4}$ Associate Professor,,${ }^{1-4}$ Dept of Forensic Medicine \& Toxicology, AFMC Pune, \\ Maharashtra, India
}

*Corresponding Author: Rashid Nehal Khan

Email: krashidnehal@ @otmail.com

\begin{abstract}
Introduction: Roads are considered a sign of development bringing a lot of advantages to people of this planet. Yet, growth of road network has brought road crashes leading to premature deaths and frequently morbidity and disability of productive age group. A study has been designed to study the pattern of injuries and associated demographic factors.

Aim \& Objective: To record the pattern of injuries after conducting the examination of the victims of Road Traffic Accident and study the demographic factors.

Results: A total of 226 patients were examined who were victims of road traffic accidents. Among victims 190 were male (84.07\%) and 36 $(15.93 \%)$ were female. $30.97 \%$ cases were seen in 21-30 years age group which was highest in different age distribution. Abrasions were most common in non fatal accidents $(54.62 \%)$ followed by contusion $(20.25 \%)$. The most common anatomical part to be injured is lower limb $(37.39 \%)$ followed by upper limb and face. Among fractures, upper limb fractures $(n=22)$ were more common than lower limb fractures $(\mathrm{n}=12)$. Most of the victims were two-wheeler riders ie $38.20 \%$. The most common site of accident was the straight roads $(45.13 \%)$ followed by highways.

Conclusion: It may be concluded that there is urgent need to address the epidemic carnage on the roads. Road traffic deaths are to a great extent preventable if due care is taken both by individual and also by the administrative authorities.
\end{abstract}

Keywords: Road Traffic Accidents, Injuries, Accident and Emergency Department.

\section{Introduction}

Among all traffic accident, road traffic accidents claim largest toll of human life and tend to be the most serious problem world over. During 1990s road traffic accident injuries ranked ninth among the leading causes of deaths in world. It is projected to become second leading cause by the year 2020 next to ischemic heart disease. About 3.5 million people die of unintentional injuries. Road traffic accidents claim 1.2 million lives. ${ }^{1}$

In India, two-thirds of road traffic injury deaths are reported in the age group 15-44 years. In 2017, officially reported road accidents were 464,910, claiming 147,913 deaths and 470,975 injured persons, that is, 405 deaths and 1,290 injuries each dayfrom 1,274 accidents. In the absence of trauma registry, adding unreported accidents, it is frightening to note this fairly high rate when compared with developed economies.An analysis of cause of death from 2002 to 2011 in a population $\geq 15$ years of age at Ballabgarh showed that $14.4 \%$ of all deaths were due to external causes and RTIs consisted of almost one-third of all deaths due to external causes. ${ }^{3}$ Hence this study was undertaken to enlist what are the pattern of injuries in road traffic accidents who report to emergency department for treatment.

\section{Aims \& Objectives}

1. To record the pattern of injuries after conducting the examination of the victims of Road Traffic Accident

2. To study the distribution of injuries in road traffic accidents in relation to selected demographic and epidemiological factors namely age, sex, role of victim at the time of accident and place of accident.

\section{Materials and Methods}

\section{Study Settings and Population}

The study was conducted on all road traffic accident cases brought to accident \& emergency department of hospital during the study period from Mar 16 to Apr 17.

\section{Inclusion Criteria}

All the cases of road traffic accident victims attending the emergency department during the study period.

\section{Exclusion Criteria}

Deaths due to RTA were excluded from the study.

\section{Sample size with justification}

All the cases reporting to the Accident \& Emergency department of this hospital satisfying the objective of study during 01 year period were part of study a total of 226 cases were studied during the study period.

\section{Data Collection and Analysis}

Data were collected both from examination of patient and by interviewing patients and relatives. Examination findings were recorded as per aim \& objective of study to study the pattern of injuries. A semi-structured interview pro forma was developed. The same was used for collecting data on various domains such as socio demographic characteristics, 
vehicle related factors and accident site related factor. The interview schedule was translated in Marathi (local language) and back - translated to English to ensure consistency. The data gathered from study was entered in Excel sheet and analyzed using SPSS software version 23.

\section{Results}

A total of 226 patients were examined who were victims of road traffic accidents. Among victims 190 were male $(84.07 \%)$ and $36(15.93 \%)$ were female. $30.97 \%$ cases were seen in 21-30 years age group which was highest in different age distribution. Abrasions were most common in non fatal accidents (54.62\%) followed by contusion $(20.25 \%)$. Most of the victims were two wheeler riders i.e $38.20 \%$. The most common site of accident was the straight roads $(45.13 \%)$ followed by highways. Max injuries were seen in lower limbs (37.39\%) followed by upper limbs $(25.02 \%)$. Injury to face was third most common (13.14\%).Abrasion was most common injury both in upper and lower limbs. Out of 39 fracture injuries 34 fractures were seen in upper and lower limbs combined.

\section{Discussion}

In our study (Table 1) it is found out that maximum number of victims of road traffic victims who reported to emergency department were of age group between 21-30 years ie $30.97 \%$, followed by $21.23 \%$ in age group $31-40$ years and $11.06 \%$ in the age group $41-50$ years. In a study published from Delhi ${ }^{4}$ it was found that max victims(47.4\%) belonged to $16-30$ years age group. Similar finding that the most vulnerable age group as regard to victim is in age bracket 20-30 years have been shown in studies from Pune, ${ }^{5}$ Shimla ${ }^{6}$ and Western Maharashtra ${ }^{7}$ also. This age is most exposed to roads for day to day necessity and also for work related purpose. It this age which commonly drives two wheelers and four wheelers and due to increased exposure, outcome also becomes directly proportional to exposure.

Present study (Table 2) shows that male were $84.07 \%$ of the victims of road traffic accidents. In a study published at Amritsar it was found that, males were predominant victims with male to female ratio of 5.72:1 $1^{8}$. Gharpure et $\mathrm{al}^{9}$ also had similar findings. In a study published at Khammam ${ }^{10}$ it was shown that $73.57 \%$ of the victims of road traffic accidents were males. All these studies corroborate the present study. It can be well said that higher percentage of male as victims of road traffic accidents can be attributed to more number of male presence on road.

The most common injury in our present study (Table3) are abrasions $(54.62 \%)$ followed by contusions (20.25\%) and lacerations $(16.55 \%)$. The most common anatomical part to be injured is lower limb (37.39\%) followed by upper limb and face. Among fractures, upper limb fractures $(\mathrm{n}=22)$ were more common than lower limb fractures $(n=12)$.In the study at Vishakapatnam. ${ }^{10} 40.7 \%$ of cases had injury of lower limb and it was the most common site of injury. In a study published in Mangalore ${ }^{11}$ the most common site of injury was abdomen (49\%). Al-Thaifani et $\mathrm{al}^{12}$ reported that the most common site of injury was lower limb $(42.18 \%)$.Similar findings as lower limb being the most common anatomical region to be injures has been reporte from studies done in Tanzania ${ }^{13}$ and Assam ${ }^{14}$.The findings from our study are in agreement with other studies where the most common site for injury was lower limb. Lower limb both covers largest area and also bears the first brunt of force in majority of road traffic accidents. Also both pedestrians and two wheeler riders are always vulnerable to lower limb injuries.

In our present study (Table 4) two wheeler riders were the most common victims (32.74\%) followed by pedestrians at $24.77 \%$. In a study at $\mathrm{Khammam}^{10}$ it was also found that $40.71 \%$ of victims were using two wheelers, $18.22 \%$ were pedestrians and $16.7 \%$ of cases were using four wheelers. This finding was similar to study done by Shah et al in Ahmedabad who found that $56 \%$ were injured by two wheelers. ${ }^{15}$ Our finding was higher when compared to study done in Pondicherry who observed that $24.4 \%$ were injured by two wheelers. ${ }^{16}$ The presence of both two wheelers and pedestrians on Indian roads are highest compared to other groups.

In our present study (Table 5) maximum spots where road traffic have taken place are straight roads. The percentage is $45.13 \%$. Highway accounted to $18.58 \%$ of accidents. Similar findings have been found in the study of Misra $\mathrm{P}$ et al ${ }^{4}$ which has revealed $56 \%$ of the road traffic accidents had been on straight roads. Our study is consistent with this study.

Table 1: Age Distribution

\begin{tabular}{|l|l|l|}
\hline Age group & Number of Cases & Percentage \\
\hline 0 - 10 years & 02 & 0.88 \\
\hline $11-20$ years & 54 & 23.89 \\
\hline $21-30$ years & 70 & 30.97 \\
\hline $31-40$ years & 48 & 21.23 \\
\hline $41-50$ years & 25 & 11.06 \\
\hline $51-60$ years & 12 & 5.30 \\
\hline $61-70$ years & 10 & 4.4 \\
\hline Above 70 years & 05 & 2.21 \\
\hline
\end{tabular}

Table 2: Sex Distribution

\begin{tabular}{|l|l|l|l|}
\hline $\begin{array}{l}\text { Number } \\
\text { of Males }\end{array}$ & $\begin{array}{l}\text { Percentage of } \\
\text { Males }\end{array}$ & $\begin{array}{l}\text { Number of } \\
\text { Females }\end{array}$ & $\begin{array}{l}\text { Percentage } \\
\text { of Females }\end{array}$ \\
\hline 190 & 84.07 & 36 & 15.93 \\
\hline
\end{tabular}


Table 3: Pattern of Injuries

\begin{tabular}{|l|l|l|l|l|l|l|}
\hline Anatomical Region & Abrasion & Contusions & Lacerations & Fractures & Others & Total \\
\hline Head & 30 & 22 & 36 & Nil & 06 & 94 \\
\hline Neck & 04 & 02 & 01 & Nil & 01 & 08 \\
\hline Face & 84 & 19 & 28 & 01 & 02 & 134 \\
\hline Chest & 42 & 26 & 03 & 04 & 06 & 81 \\
\hline Abdomen & 23 & 22 & 16 & Nil & 08 & 69 \\
\hline Upper Limbs & 156 & 35 & 32 & 22 & 12 & 257 \\
\hline Lower Limbs & 222 & 82 & 54 & 12 & 14 & 384 \\
\hline & 561 & 208 & 170 & 39 & 49 & 1027 \\
\hline
\end{tabular}

Table 4: Victims Role at the time of Accident

\begin{tabular}{|l|l|l|}
\hline Victims Role & $\begin{array}{l}\text { Number of } \\
\text { Cases }\end{array}$ & $\begin{array}{l}\text { Percentage of } \\
\text { Cases }\end{array}$ \\
\hline Pedestrian & 56 & 24.77 \\
\hline Two wheeler Rider & 74 & 32.74 \\
\hline Two wheeler Pillion & 28 & 12.38 \\
\hline Four wheeler Driver & 42 & 18.58 \\
\hline Four wheeler passenger & 26 & 11.50 \\
\hline
\end{tabular}

Table 5: Place of Accident

\begin{tabular}{|l|l|l|}
\hline Place of Accident & Number of Cases & Percentage \\
\hline Straight Road & 102 & 45.13 \\
\hline Highway & 42 & 18.58 \\
\hline Wrong Direction & 22 & 9.73 \\
\hline U Turn & 32 & 14.15 \\
\hline Busy narrow streets & 28 & 12.38 \\
\hline
\end{tabular}

\section{Conclusion}

It may be concluded that there is urgent need to address the epidemic carnage on the roads. Road traffic deaths are to a great extent preventable. Traffic safety education should be given in schools for production of skilled and responsible drivers/road users in future. Moreover, the recommendations from the world report on road traffic injury prevention should be considered and promptly implemented. The awareness among both users of road and administrators about road travel discipline should be very high in order to curb the ever rising epidemic of road traffic accidents.

\section{Source of Funding: None.}

\section{Conflict of Interest: None.}

\section{Reference}

1. Ranjan R, Kumar D, Lal SP. Pattern And Distribution of Injuries in Fatal Road Traffic Accident Cases . IOSR J Dental Med Sci 2017;16 (3):71-4.

2. Pal R, Ghosh A, Kumar R, Galwankar S, Paul SK, S Pal S. Public health crisis of road traffic accidents in India: Risk factor assessment and recommendations on prevention on the behalf of the Academy of Family Physicians of India. J Family Med Prim Care 2019;8(3):774- 83.

3. Rai SK, Gupta A, Srivastava R, Bairwa M, Misra P, Kant S. Decadal transition of adult mortality pattern at Ballabgarh HDSS: Evidence from verbal autopsy data. BMC Public Health 2015;15:781.
4. Misra P, Majumdar A, Misra MC, Kant S, Gupta S, Amit Gupta, Kumar S.Epidemiological Study of Patients of Road Traffic InjuriesAttending Emergency Department of a Trauma Center in New Delhi. Indian J Crit Care Med 2017; 21:678-83.

5. Pathak SM, Jindal AK, Verma AK, Mahen A. An epidemiological study of road traffic accident cases admitted in a tertiary care hospital. Med JArmed Forces India 2014;70:325.

6. Mahajan N, Aggarwal M, Raina S, Verma LR, Mazta SR, Gupta BP,et al. Pattern of nonfatal injuries in road traffic crashes in a hilly area:A study from Shimla, North India. Int $J$ Crit Illn Inj Sci 2013;3:190-4.

7. Patil SS, Kakade R, Durgawale P, Kakade S. Pattern of road traffic injuries: A study from Western Maharashtra. Indian $J$ Community Med 2008;33:56-7.

8. Bal V, Singh T, Singh, T, Deepti SS. An Epidemological Study of Road Traffic Injuries Reporting in Casualty Department of Guru Nanak Dev Hospital, Amritsar. J Med Sci Clin Res 2018;6(1):607-15.

9. Gharepure PV, Jhala CI, Nair MB .Accidents. Ind. J Ned Sci 1959;13(3):232.

10. Neeluri R, Anga VS. A study on victims of road traffic accidents attending casualty in a tertiary care hospital Khammam. Int J Community Med Public Health. 2018;5(7):3034-8.

11. RaviKiran E, Saralaya KM, Vijaya K. Prospective study on Road Traffic Accidents. JPAFMAT 2004;4:12-6.

12. Al-Thaifani AA, Al-Rabeei NA, Dallak AM. Study of the Injured Persons and the Injury Pattern in Road Traffic Accident in Sana'a City, Yemen. Adv Public Health 2016;1-5.

13. Chalya PL, Mabula JB, Dass RM. Injury characteristics and outcome of road traffic crash victims at Bugando Medical Centre in Northwestern Tanzania. J Trauma Manag Outcomes 2012;6(1).

14. Bhuyan PJ, Ahmed F. Road traffic accident: an emerging public health problem in Assam. Indian J Community Med 2013;38(2):100-4.

15. Shah A, Jarwani B. Study of victims of road traffic accidents arriving in emergency department of V.S hospital at Ahmedabad city, single centre pilot study. NHL J Med Sci 2014;3(2):23-6

16. Jha N, Srinivasa DK, Gautam R, Jagdish S. Epidemiological study of Road Traffic Accident cases: A study from South India. Indian J Community Med. 2004;29(1):20-4.

How to cite this article: Chaturvedi Y, Khan RN, Rautji $\mathrm{R}, \mathrm{K}$ V Radhakrishna. Pattern of injuries in road traffic accidents cases reporting to accident and emergency department of a hospital in Maharashtra. Int J Forensic Med Toxicol Sci 2019;4(4):140-2. 